\title{
AN ASSESSMENT OF THE INTERNAL DETERMINANTS OF THE ENVIRONMENTAL DISCLOSURE PRACTICES OF FIRMS ACROSS SUB-SAHARAN AFRICA
}

\author{
Edirin Jeroh ${ }^{*}$ \\ Delta State University, Department of Accounting, Abraka, Delta State, Nigeria
}

This paper comparatively analyzes the internal determinants of environmental disclosure practices among firms in Sub-Saharan Africa (SSA). To achieve this, secondary data on the characteristics of the measures of the board and the characteristics of the audit committee were obtained from a sample of 60 companies from across the region (20 each from Kenya, Nigeria and South Africa). The regression technique was used to analyze the data and the results revealed the fact that, while the characteristics of the measures of the board and the audit committee were found to be the significant determinants of the environmental disclosure of firms in Kenya and Nigeria, the same cannot be said of firms in South Africa. The study, therefore, recommends that borrowing from South Africa, environmental management practices should be institutionalized in the entire region. Additionally, standard-setters should make practical efforts by developing new reporting standards which will guide and encourage a full disclosure of environmental concerns by firms.

Keywords: Sub-Saharan Africa, disclosure requirements, financial reporting, environmental management, corporate governance, board of directors

JEL Classification: G34, M40, M41

\section{INTRODUCTION}

Globally, organizations have been confronted with a variety of environmental and ecological concerns affecting their respective operations and activities at different magnitudes. Despite the existence of such environmental concerns, the natural environments within which firms operate have metamorphosed into

* Correspondence to: E. Jeroh, Delta State University, Department of Accounting, Abraka, Delta State, Nigeria; e-mail: jeroh4laffs@gmail.com the avenues through which competitive advantage might be gained. While we agree with the arguments that firms may gain competitive advantage from their immediate environment, the fact that such firms, their host communities and the entire ecosystem have been faced with the degrees of environmental decadence ranging from very minute to a variety of severe environmental hazards cannot be overemphasized. This has spurred the studies that have continuously affirmed the need for improved environmental performance, environmental disclosure requirements 
and further calls for firms to be more environmentally friendly (Raath, Kanyimba, De Sousa \& Richter, 2018; Qian, Hörisch \& Schaltegger, 2018).

However, due to exigencies resulting from the performance of a growing number of environmental responsibilities among firms and across sectors, environmental performance has evolved in the accounting literature as the focal concept of discourse (Makori \& Jagongo, 2013; Hoje, Kim \& Park, 2014). So far, researchers have examined the determining factors of the pro-environmental behavior of firms and the assumed link between environmental reporting and the concepts such as corporate governance, firm performance and disclosure practices, among others (Cong \& Freedman, 2011; Latridis, 2013; Mnasri, 2015; Jones, Jackson, Bates \& Tudor, 2016; Adinehzadeh, Jaffar, Shukor, \& Abdul Rahman, 2018; Mata, Fialho \& Eugénio, 2018). Noteworthy, the outcomes of the accounting research studies conducted to date have suggested that the absence of disclosures on environmental costs and associated activities in firms' published annual reports have ultimately amounted to a rout to the very essence of financial reporting since the fundamental qualitative characteristics of the accounting information of "relevance" remains questionable (Uwuigbe \& Egbide, 2013; Makori \& Jagongo, 2013). This is why E. Jeroh and E. G. Okoro (2016) reiterated the fact that environmental reporting had become the basic necessity at corporate levels.

This study primarily sets out to comparatively examine the internal determinants of environmental disclosure practices by obtaining empirical evidence from a cross-section of firms in Sub-Saharan Africa (SSA).

Bearing in mind the foregoing research subject, the research goal of the study is to ascertain whether the characteristics of the measures of the board and the audit committee have a significant influence on environmental disclosure practices among the listed firms in SSA. The study is empirically oriented and employs quantitative methods (descriptive and inferential statistics alongside diagnostic tests). The study's outcomes are useful to Corporate Boards, organizational personnel at managerial cadres, regulatory bodies/agencies and generally the stakeholders of firms across the countries in SSA.

Beside the introductory and concluding sections, this paper also majorly consists of the other four sections: first, there is a problem statement, which is followed by the second, i.e. a literature review and the theoretical background of the study. The third section deals with the method applied in the study, while the fourth dwells upon the results.

\section{PROBLEM STATEMENT}

Most countries in SSA have migrated to or adopted the global reporting standards (International Financial Reporting Standards - IFRS) for the purpose of reporting and presenting financial statements. Interestingly, when reporting with the existing national and/or global accounting standards, environmental and related costs do not appear as separate line items in the income statements of firms (Aurelia-Aurora \& Sorina-Geanina, 2012). Thus, firms sometimes disclose such related costs on a voluntary basis, especially so where legislations and regulatory pronouncements on such matters are minimal or absolutely absent. According to N. H. Sheila, H. M. Rashid, A. A. Mohammed and A. K. Meera (2012), the choice of reporting the relevant data that may be useful for stakeholders' information needs largely depends on a variety of the characteristics of the firm and the measures of corporate governance. Impliedly, these corporate governance measures may, therefore, be considered as the vital requirements for or determinants of corporate environmental and social disclosures among firms. This assumption is in line with the views expressed by authors such as R. M. Haniffa and T. E. Cooke (2005); M. A. Ali and R. H. Attan (2013).

Despite the growing body of the extant studies on environmental and social disclosure among firms (Delmas \& Toffel, 2008; Cong \& Freedman, 2011; Aurelia-Aurora \& Sorina-Geanina, 2012; Cho \& Patten, 2013; Lu \& Abeysekera, 2014; Meng, Zeng, Shi, Qi \& Zhang, 2014; Michelon, Pilonato \& Ricceri, 
2015; Md Nor, Bahari, Adnan, Kamal \& Ali, 2016; Brooks \& Oikonomou, 2018; Husted \& de SousaFilho, 2018; Mata, Fialho \& Eugénio, 2018), it may clearly be observed that this concept is yet to receive broad attention in the accounting literature within developing economies and, by extension, within the region of Sub-Saharan Africa (Delmas \& Toffel, 2008). Additionally, the few studies on the concept of environmental accounting and/or disclosure of firms that have sprouted within the region are mainly focused on specific sectors, such as oil and gas, banking, cooperatives and manufacturing sectors, respectively (Uwuigbe, 2012; Jeroh \& Okoro, 2016; Mathuva \& Kiweu, 2016; Ashafoke \& Ilaboya, 2017). More worrisome is the fact that these studies are country-specific, devoid of any form of the comparative analysis of firms across the region of SSA, thus making the policy implication of such studies restrictive in terms of coverage and application in other jurisdictions. This has, however, created an empirical gap which this current study sets out to fill.

Besides, given the need for continuous research studies aimed at examining the determinants of environmental disclosure practices, especially as regulatory requirements for an improvement in corporate reporting and the governance of firms, is currently experiencing a dramatic turnaround, this study striving to ascertain the level of environmental disclosures by firms across the sub-region through the examination of the level of the variability of environmental disclosure practices across different jurisdictions in SSA.

In light of the above, this study sets out to:

- comparatively examine whether the measures of the board structure (the board size, the board gender diversity and the board independence) and the measures of the audit committee (the size, diligence and independence of audit committees) are significant determinants of the environmental disclosure of the selected, listed firms across countries in SSA, and

- ascertain whether there is a significant variation in the environmental disclosure practices among the listed firms in SSA.
Given the foregoing, the following is hypothesized:

H1: The characteristics of the measures of the board and the audit committee do not have a significant influence on the environmental disclosure practices among the listed firms in SSA.

$\mathrm{H} 2$ : There is no significant variation of the determinants of the environmental disclosure practices among the countries in SSA.

\section{LITERATURE REVIEW AND THEORETICAL BACKGROUND}

\section{The Concept of Environmental Disclosure}

Environmental disclosure is the act of identifying, measuring, allocating, and/or integrating costs related to greenhouse/carbon emission and other environmental concerns in the financial statements of firms. In a similar fashion, environmental disclosure refers to the conscious efforts targeted at the provision of useful information on environmental concerns. D. M. Makori and A. Jagongo (2013) believe that environmental disclosure implies reporting every piece of information on social costs which may have been incurred by firms as a result of production externalities on the environment. Environmental disclosure also reveals the level of the sustenance of regular intervention costs designed to bridge a gap between marginal and total costs reported in companies' financial statements.

Environmental disclosure remains a part and parcel of firms' social responsibility disclosures. The term Social Responsibility Disclosures (SRD) refers to the totality of all disclosures pertaining to increasing interactions between reporting entities and their respective physical/social environment (Deegan, Rankin \& Voght, 2000). According to D. Campbell (2003), the term "environmental disclosures" refers to any disclosure pertaining to the effect of a company's operations on the immediate natural or operating environment. Impliedly, environmental disclosure 
reports all information on environmental concerns, with details of their respective financial implications for the company's environmental management and other strategic decisions, actions and/or operations.

Depending on the user group, research evidence has shown that environmental reports are useful tools in satisfying stakeholders' decision-making needs (Kamala, Wingard \& Cronjé, 2015; Liu, Yin, Pengue, Benetto, Huisingh, Schnitzer, Wang \& Casazza, 2018). The trends in environmental disclosure practices among firms have undoubtedly changed recently, having attracted researchers, policymakers, management and practitioners in different jurisdictions (Buysse \& Verbeke, 2003; Delmas \& Toffel, 2008). In fact, environmental disclosure is mainly directed towards achieving good corporate governance aimed at guaranteeing transparency promotion in all facets/spheres of societal activities (Ashafoke \& Ilaboya, 2017).

\section{Theoretical Framework}

Legitimacy Theory provides the theoretical base upon which this study hinges. According to A. N. Nwaobia (2015), the nub of this theory is derived from the tenets of the organizational legitimacy discourse that posits that there are social contracts between companies and the respective societies they operate in. Thus, legitimacy theory presents the multi-faceted expectations of societies and the manner how firms should conduct their multidimensional operations amidst societal demands. Arguably, societies will allow companies to continuously operate given certain synergistic factors. The management of firms will therefore adopt copious strategies designed to give the society the assurance that societal values and norms will at all times be complied with.

In assessing the internal determinants of environmental disclosure practices among firms, this paper draws from the existing arguments in the prior literature (Mousa \& Hassan, 2015; Nwaobia, 2015; Zysnarska-Dworczak, 2018) and aver that, in disclosing environmental and related financial information, firms are guided by legitimacy theory, which helps them better understand how to develop, implement and communicate their respective company policies on social responsibility and environmental concerns. It is on this note that companies strive for accountability in providing value-relevant information through full disclosure in financial reporting.

Since the theory provides insights useful for our understanding companies' practices regarding social environmental disclosure and the disclosure of related issues (Mousa \& Hassan, 2015), this study hinges upon the tenets of legitimacy theory.

\section{Prior Empirical Review of Environmental Disclosure Determinants}

The growing awareness of and stakeholders' expectations regarding the responsibilities of firms pertaining to greenhouse emissions and other environmental concerns have given birth to renewed research interests in environmental accounting, environmental performance and the disclosure quality of firms within and outside the SSA region. Accordingly, the study by A. Ahmad (2012) sets out to investigate environmental accounting and the reporting practices of the sampled firms in Bangladesh. The study relied on the primary and secondary data obtained from the financial reports of the firms selected for the study. Analyses were carried out with the help of descriptive, diagnostic and inferential statistics, and the findings revealed, among other things, that the Bangladeshi companies had a strong desire for environmental disclosure although, with but very few exceptions, most information on environmental concerns was qualitative by its nature and was mainly found in directors' or chairmen's/ managing directors' statements.

D. Aurelia-Aurora and M. S. Sorina-Geanina (2012) examined how environmental information were presented and disclosed by Romanian companies. The study, however, analyzed the notable factors presumed to have influenced the manner in which environmental accounting had been developing over years. Additionally, a content analysis was conducted 
of the nature and type of the environmental information disclosed by the listed Romanian firms. The study found that a total of $80 \%$ of the financial statements of the sampled companies had disclosures on sustainable development studies although very few companies had reports on the fines and penalties resulting from environmental pollution. The study, however, pointed out the fact that such reports on penalties and fines might have negative connotations for reporting entities.

N. D. Mchavi, and C. C. Ngwakwe (2017) examined the effect environmental pressure would exert on the level of environmental disclosure among banks in South Africa. The study relied on a mixture of the qualitative and quantitative data covering the period from 2010 to 2015. A content analysis was conducted in order to obtain relevant data from the sustainability reports of only three sampled banks, whose records had consistent data for the given period and across all the variables. The panel data and multiple regression techniques were employed and the analysis was based on the results that emanated from descriptive and inferential statistics. Overall, the study observed that the measures of environmental pressure had no significant influence on the environmental disclosure of South African banks. Therefore, the study calls for further studies aimed at finding out the reason why the disclosure practices of the banks had no relationship with the environmental pressure present in the country.

D. M. Mathuva and J. M. Kiweu (2016) analyzed the link between Cooperative Social and Environmental Disclosure (CSED) and the levels of the financial performance of Kenyan Savings and Cedit Cooperatives (SACCOs). However, the data were obtained from the financial reports of the 212 registered SACCOs over a six-year period spanning from 2008 to 2013, which resulted in a total of 1272 empirical observations. The analysis was based on the panel OLS approach. The empirical evidence revealed a relatively low level of environmental disclosure among the Kenyan SACCOs. Additionally, the relationship between CSED and the financial performance of SACCOs in Kenya was found to be negative. Thus, the study argued that the trend might be a result of transition in the regulatory landscape of SACCOs in Kenya.

In a Nigerian study by S. J. Musa, T. Peter and M. Bukar (2015), efforts were made to examine the environmental accounting/disclosure practices of the listed firms in the consumer goods sector. The main thrust of the study was to ascertain the extent to which global accounting standards (IFRS) had influenced environmental disclosure practices among Nigerian firms. The study adopted content analysis and the data were extracted from the annual financial reports of the sampled consumer goods companies in the fiscal year 2013. The study found that the accounting standards were not the significant determinants of environmental accounting disclosure; hence, the adoption of the IFRS had no significant influence on disclosures regarding environmental accounting.

In a more recent study by L. S. Nguyen and M. D. Tran (2019), the link between the disclosure levels of firms' environmental concerns and their performance (proxied by ROA) was examined by obtaining the evidence from the listed companies in Vietnam. The quantitative data were compiled from the financial records of the sampled firms, covering a five-year period from 2013 to 2017. The analysis was based upon two regression models. The findings of the study suggested a close association between the firms' disclosure of environmental financial data and their performance.

\section{METHODS}

This research study adopts the ex-post facto design and relies on the secondary data of the selected, listed firms in the most active and most capitalized stock markets in the three regions of SSA - East Africa, West Africa and South Africa. These stock markets are the Nairobi Stock Exchange (NSE), Kenya (East Africa); the Nigerian Stock Exchange (NGSE), Nigeria (West Africa), and the Johannesburg Stock Exchange (JSE), South Africa. As at 31st December 2017, all the three stock exchanges had a summation of 619 listed firms (Table 1). 
Table 1 The study population

\begin{tabular}{c|cc}
\hline S/N & Name of country & Number of listed firms \\
\hline 1 & South Africa & 386 \\
2 & Nigeria & 170 \\
3 & Kenya & 63 \\
& Total & 619 \\
\hline
\end{tabular}

Source: The Stock Exchanges of the respective countries, (2018)

However, as many as 20 firms were randomly selected for each country from within the companies whose stocks were actively being traded throughout the study period. This produced a total sample of 60 firms (20 firms from each country). The secondary data on the variables of interest were, therefore, obtained from the financial statements of the sampled firms for a six-year period, spanning from 2012 to 2017.
For the purpose of the analysis, the panel technique was adopted, based on the following model:

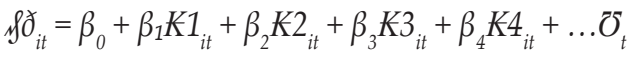

Where:

$$
\begin{array}{ll}
\qquad \delta_{i t} & =\text { the dependent variable } \\
K 1_{i t} \ldots K 4_{i t} & =\text { the explanatory variables } \\
\beta_{0} \ldots \beta_{4} & =\text { the Beta coefficients } \\
\delta_{t} & =\text { the error term }
\end{array}
$$

Based on the foregoing basic OLS model, specific models were derived to test the postulated hypothesis, thus:

$$
\begin{aligned}
\mathrm{ENVD}_{i t}= & \beta_{0}+\beta_{1} \text { BODSZ }_{i t}+\beta_{2} B O D G D V_{i t}+\beta_{3} \text { BODIND }_{i t}+ \\
& \beta_{4} A U D S Z_{i t}+\beta_{5} A U D G D V_{i t}+\beta_{6} A \operatorname{AUDIND}_{i t}+ \\
& \beta_{7} \mathrm{CSIZ}_{i t}+U_{t}
\end{aligned}
$$

\begin{tabular}{|c|c|c|c|}
\hline Variables & Variable Type & Label & Proxy/Measure \\
\hline $\begin{array}{l}\text { Environmental } \\
\text { Disclosure }\end{array}$ & Dependent Variable & ENVD & $\begin{array}{l}\text { The dummy variable of } 1 \text { for each year environmental } \\
\text { disclosure is made, otherwise } 0 .\end{array}$ \\
\hline Board Size & Independent Variable & BODSZ & $\begin{array}{l}\text { The number of the members of the company's Board of } \\
\text { Directors in the given year. }\end{array}$ \\
\hline Board Gender Diversity & Independent Variable & BODGDV & $\begin{array}{l}\text { The proportion of female Board members against the } \\
\text { total Board members in the given year. }\end{array}$ \\
\hline Board Independence & Independent Variable & BODIND & $\begin{array}{l}\text { The proportion of the external, independent directors } \\
\text { against the total Board size. }\end{array}$ \\
\hline Audit Committee Size & Independent Variable & AUDSZ & The total number of members in the committee. \\
\hline $\begin{array}{l}\text { Audit Committee } \\
\text { Diligence }\end{array}$ & Independent Variable & AUDDIL & $\begin{array}{l}\text { The number of the meetings held and attended during } \\
\text { the financial year. }\end{array}$ \\
\hline $\begin{array}{l}\text { Audit Committee } \\
\text { Independence }\end{array}$ & Independent Variable & AUDIND & $\begin{array}{l}\text { The proportion of the external, independent directors in } \\
\text { the audit committee against the total committee size. }\end{array}$ \\
\hline Company Size & Control Variable & CSIZ & The natural log of each company's total assets in a year. \\
\hline
\end{tabular}

The variables in (2) above are, however, defined and described in Table 2.

Table 2 The definition and description of the variables

Source: Author 


\section{RESULTS}

Prior to the presentation of the results of the inferential statistics, the results of the descriptive statistics and the diagnostic tests were presented and analyzed. The indications from Table 3 show that the average value of the dependent variable (ENVD) is 0.6917 , with a very low standard deviation of about 0.4624 . The low standard deviation indicates a low level of the dispersion of the respective firm-level data from the mean. Again, it is possible to notice that the variables of the board characteristics (BODSIZ, BODGDV and BODIND) showed the related dispersion level. When the audit committee characteristics are concerned, it is clear that, apart from AUDIND, the level of the dispersion of the data set from the mean showed a very low trend. The minimum and maximum values of the respective variables are also presented in the table. The results of descriptive statistics are usually used to show the nature of the data generated for any given study.

The result of the correlation analysis is also presented so as to show the direction of the relationship among the variables and confirm whether there are possible signals of the presence of multicollinearity among the data set. The result of the correlation analysis is presented in Table 4.

Table 3 The summary of the descriptive statistics for all the panel data

\begin{tabular}{c|ccccc}
\hline Variable & Mean & $\begin{array}{c}\text { Std. } \\
\text { Dev. }\end{array}$ & $\begin{array}{c}\text { Min. } \\
\text { Value }\end{array}$ & $\begin{array}{c}\text { Max. } \\
\text { Value }\end{array}$ & N \\
\hline ENVD & 0.6917 & 0.4624 & 0 & 1 & 360 \\
BODSIZ & 11.6417 & 3.5509 & 4 & 25 & 360 \\
BODGDV & 16.0443 & 10.7138 & 0 & 50 & 360 \\
BODIND & 70.8331 & 13.5373 & 25 & 94.44 & 360 \\
AUDSZ & 5.075 & 1.4881 & 2 & 11 & 360 \\
AUDDIL & 4.3778 & 1.3524 & 2 & 12 & 360 \\
AUDIND & 78.7058 & 25.6969 & 20 & 100 & 360 \\
CSIZ & 14.1089 & 1.7354 & 10.19 & 18.33 & 360 \\
\hline
\end{tabular}

Source: Author

Table 4 The correlation matrix for all the panel data

\begin{tabular}{|c|c|c|c|c|c|c|c|c|}
\hline & ENVD & BODSZ & BODGDV & BODIND & AUDSZ & AUDDIL & AUDIND & CSIZ \\
\hline ENVD & 1.0000 & & & & & & & \\
\hline BODSIZ & 0.3481 & 1.0000 & & & & & & \\
\hline BODGDV & 0.2340 & 0.2007 & 1.0000 & & & & & \\
\hline BODIND & 0.0861 & 0.0925 & 0.0133 & 1.0000 & & & & \\
\hline AUDSZ & -0.0756 & 0.1548 & -0.0016 & -0.1673 & 1.0000 & & & \\
\hline AUDDIL & 0.0487 & 0.0897 & 0.1450 & 0.1457 & -0.1179 & 1.0000 & & \\
\hline AUDIND & 0.2641 & 0.0811 & 0.1414 & 0.4142 & -0.6626 & 0.2624 & 1.0000 & \\
\hline CSIZ & 0.3925 & 0.6448 & 0.2156 & 0.0307 & 0.1426 & 0.1847 & 0.0630 & 1.0000 \\
\hline
\end{tabular}

Source: Author 
The correlation results reveal that, apart from the Audit Committee Size (AUDSZ), all the explanatory variables demonstrated a positive association with the Environmental Disclosure (ENVD) of the sampled firms. Also, the correlation coefficient between the pairs of the explanatory variables ranged from 0.0016 (between BODGDV and AUDSZ) and 0.6626 (between AUDSZ and AUDIND). However, no pair of the explanatory variables indicated the signs of the presence of multicollinearity. This is because the correlation coefficients obtained were less than the threshold value of 0.8 . The data were further subjected to the tests for multicollinearity and heteroscedasticity by using the Variance Inflation Factor (VIF) and the Breusch Pagan Cooke/Weisberg tests, respectively. Table 5 reveals the mean VIF of 1.64, with the VIF results for each independent variable ranging from 1.09, for BODGDV, to 2.40, for AUDIND. The result of the Breusch Pagan Cooke/Weisberg test further produced a chi2(1) value of 15.20 with a p-value of 0.0001 . These results, however, confirm the fact that the model specified for this study is fit and meets the minimum condition for the OLS regression analysis.

\section{COMPARATIVE OLS REGRESSION RESULTS ACROSS THE SAMPLED COUNTRIES}

The summary of the OLS results for each country is presented in Table 6.
Table 6 The summary of the OLS regression results across the sampled countries

\begin{tabular}{l|ccc}
\hline Statistics & Kenya & Nigeria & South Africa \\
\hline $\mathrm{F}(7,112)$ & 2.84 & 6.37 & 1.51 \\
Prob $>\mathrm{F}$ & 0.0091 & 0.0000 & 0.1723 \\
R-Squared & 0.1509 & 0.2847 & 0.086 \\
Adj.R-Squared & 0.0979 & 0.2400 & 0.0289 \\
\hline
\end{tabular}

Source: Author

In Table 6, a comparative summary of the OLS regression results for the sampled firms on a countryby-country basis is presented. The $\mathrm{F}$ statistics obtained for Kenya $($ Fcal $=2.84 ;$ p-value $=0.0091)$ and Nigeria $($ Fcal $=6.37 ; p$-value $=0.0000)$ revealed that the characteristics of the board and the audit committee were in a significant relationship with environmental disclosure, but the same cannot be said for South Africa, where the F-value obtained was 1.51, with a p-value of 0.1723 . A further analysis of the results in Table 6 shows that about $15.09 \%$ of environmental disclosure practices in Kenya were caused by the characteristics of the board and the audit committee, whereas about $28.47 \%$ of environmental disclosure practices in Nigeria could be attributable to the characteristics of the board and the audit committee. In South Africa, we observed that no relationship could have been established between environmental disclosure practices among the firms and the characteristics of their respective boards and audit committees. The above results imply that, for South

Table 5 The results for further diagnostic tests

\begin{tabular}{ccccccccc}
\hline Variable & AUDIND & AUDSZ & CSIZ & BODSIZ & BODIND & AUDDIL & BODGDV & Mean VIF \\
\hline VIF & 2.40 & 2.01 & 1.80 & 1.79 & 1.25 & 1.12 & 1.09 & 1.64 \\
1/VIF & 0.4169 & 0.4980 & 0.5566 & 0.5600 & 0.7989 & 0.8904 & 0.9166 & chi2(1) =15.20; Prob >chi2(1)=0.0001 \\
\hline \multicolumn{7}{c}{$\begin{array}{c}\text { Breusch Pagan Cooke/Weisberg } \\
\text { Test for Heteroscedasticity }\end{array}$} & & \\
\hline
\end{tabular}

Source: Author 
Africa, the environmental disclosure practices of firms cannot be significantly attributed to the internal factors/governance attributes of the respective firms. It is, therefore, possible that the choice of and compliance with environmental disclosure among South African firms are predetermined by the factors that are external to the firm, which are definitely beyond the scope of this current study. Noteworthy, this result is in consonance with the expectation in the literature, since the existing regulatory provisions require that South African firms should prepare and disclose their respective sustainability reports (Mchavi \& Ngwakwe, 2017).

With respect to the results for Nigeria and Kenya, it can be noticed that the composition and nature of the boards of the listed firms and their respective audit committees directly or indirectly affect their practices towards environmental disclosures. It is therefore possible that the level of compliance with the regulatory pronouncements by the financial reporting councils (or other applicable regulatory bodies) pertaining to environmental concerns largely depends on the attributes of the boards and audit committees, which in turn affects the environmental disclosure practices of the companies in Kenya and Nigeria.

Given the foregoing results, it is obvious that, in the South African context, the practice of sustainability reporting has compelled firms to mandatorily disclose environmental information in their annual reports. The same cannot be said for Nigeria and Kenya. This development, however, has policy implications for financial reporting in the SSA region and, by extension, developing economies.

\section{CONCLUSION}

Globally, there have been increased concerns about the environmental hazards and environmental threats posed to the ecosystem due to various operations and business or due to the other activities conducted by companies generally. This is why the concept of environmental accounting and disclosure practices has assumed the central place in topical discourse/debates among leading scholars. Despite this growing concern about environmental disclosure, empirical evidence has not established whether the determinants of environmental disclosure vary across countries in SSA, or not. However, this study sets out to comparatively ascertain the internal determinants of the environmental disclosure across the selected firms in SSA. The focus of the study was on the characteristics of the board and the audit committee as the possible determinants of environmental disclosure among firms.

Importantly, it was discovered that the internal determinants of environmental disclosure practices vary across countries in SSA. Specifically, while it can be noticed that the characteristics of the measures of the board and the audit committee were the significant determining factors of the environmental disclosure practices of the firms in Kenya and Nigeria, the same was not the case in South Africa. This result has policy implications for and calls for the need to examine the corporate governance and regulatory architecture of SSA countries SSA.

According to the results, the disclosure of environmental concerns among South African firms may not necessarily be significantly attributable to the internal factors, such as governance attributes. This means that the firms' compliance level regarding environmental disclosure in South Africa may possibly be predetermined by the external factors, such as regulatory provisions, which require that South African firms should prepare and disclose their respective sustainability reports. Given the aforesaid, the hypotheses stated in the study have been rejected since.

Based on the findings of the study, the following is recommended:

- According to the trend in South Africa, Environmental Management Practices (EMP) should be institutionalized through policies and guidelines among firms throughout the SSA region.

- Regulators in different countries in the SSA region should urgently design and implement the policies 
that will make it mandatory for companies to prepare environmental and sustainability reports as a part of their disclosure requirements.

- The regional professional accounting bodies and financial accounting regulators are, therefore, invited to actively involve themselves in the process of institutionalizing EMP.

Standard-setters should make practical efforts by developing the new reporting standards that will guide and encourage the full disclosure of environmental concerns by firms.

However, this study is limited in scope, as it only covers the characteristics of the measures of the board and the attributes of the audit committee as the possible internal determinants of environmental disclosures among the firms. It is, therefore, suggested that future research studies should extend this scope by examining the link between environmental disclosure practices and firms' attributes, such as the capital structure, profitability measures and company policies, among other things. Given the fact that this study only focused on the internal determinants, research studies may also be conducted in order to ascertain all such external factors that, for the most part, drive environmental disclosure practices among firms.

\section{REFERENCES}

Adinehzadeh, R., Jaffar, R., Shukor, Z. A., \& Abdul Rahman, M. R. C. (2018). The mediating role of environmental performance on the relationship between corporate governance mechanisms and environmental disclosure. Asian Academy of Management Journal of Accounting and Finance, 14(1), 153-183.

Ahmad, A. (2012). Environmental accounting and reporting practices: Significance and issues: A case from Bangladeshi companies. Global Journal of Management and Business, 12(14), 119-127.
Ali, M. A., \& Attan, R. H. (2013). The relationship between corporate governance and corporate social responsibility disclosure: A case of Malaysian sustainability companies and global sustainability companies. South East Asia Journal of Contemporary Business, Economics and Law, 1(3), 39-48.

Ashafoke, T. O. \& Ilaboya, J. (2017). Board characteristics and environmental disclosure in Nigeria banking sector. ICAN Journal of Accounting and Finance, 6(1), 87-102.

Aurelia-Aurora, D., \& Sorina-Geanina, M. S. (2012). Perspectives of environmental accounting in Romania. Procedia - Social and Behavioral Sciences, 62(October), 610-614. doi.org/10.1016/j.sbspro.2012.09.102

Brooks, C., \& Oikonomou, I. (2018). The effects of environmental, social and governance disclosures and performance on firm value: A review of the literature in accounting and finance. The British Accounting Review, 50(1), 1-15. doi.org/10.1016/j.bar.2017.11.005

Buysse, K. \& Verbeke, A., 2003. Proactive environmental strategies: a stakeholder management perspective. Strategic Management Journal, 24(1), 453-470.

Campbell, D. (2003). Intra and inter-sectoral effects in environmental disclosures: Evidence for legitimacy theory? Business Strategy and the Environment, 12(6), 357-371. doi.org/10.1002/bse.375

Cho, C. H., \& Patten, D. M. (2013). Green accounting: Reflections from a CSR and environmental disclosure perspective. Critical Perspectives on Accounting, 24(6), 443447. doi.org/10.1016/j.cpa.2013.04.003

Cong, Y., \& Freedman, M. (2011). Corporate governance and environmental performance and disclosures. Advances in Accounting, 27(2), 223-232. doi.org/10.1016/j.adiac.2011.05.005

Deegan, C., Rankin, M., \& Voght, P. (2000). Firms' disclosure reaction to major social incidents: Australian evidence. Accounting Forum, 24(1), 101-130.

Delmas, M. A., \& Toffel, M. W. (2008). Organisational responses to environmental demands: Opening the black box. Strategic Management Journal, 29(10), 1027-1055. doi. org/10.1002/smj.701

Haniffa, R. M., \& Cooke, T. E. (2005). The impact of culture and governance on corporate reporting. Journal of Accounting and Public Policy, 24(5), 391-430. doi.org/10.1016/j. jaccpubpol.2005.06.001 
Hoje, J., Kim, H., \& Park, K. (2014). Corporate environmental responsibility and firm performance in the financial services sector. Korea Advanced Institute of Science and Technology, Working Paper, Series No. 2014-007. Korea: AIST.

Husted, B. W., \& de Sousa-Filho, J. M. (2018). Board structure and environmental, social and governance disclosure in Latin America. Journal of Business Research, Forthcoming. DOI: https://doi.org/10.1016/j.jbusres.2018.01.017.

Jeroh, E., \& Okoro, E. G. (2016). Effect of environmental and dismantling costs on firm performance among selected oil and gas companies in Nigeria. Sahel Analyst: Journal of Management Science, 14(5), 14-26.

Jones, J., Jackson, J. I., Bates, M., \& Tudor, T. (2016). Factors influencing corporate pro-environmental bahaviour - A case study from the UK construction sector. International Journal of Environment and Sustainable Development, 15(1), 1-15. doi.org/10.1504/IJESD.2016.073314

Kamala, P. N., Wingard, C., \& Cronjé, C. (2015). Evolution of corporate environmental reports in South Africa. Journal of Accounting and Management, 50(2), 31-44.

Latridis, G. E. (2013). Environmental disclosure quality: Evidence on environmental performance, corporate governance and value relevance. Emerging Markets Review, 14(March), 55-75. doi.org/10.1016/j.ememar.2012.11.003

Liu, G., Yin, X., Pengue, W., Benetto, E., Huisingh, D., Schnitzer, H., Wang, Y., \& Casazza, M. (2018). Environmental accounting: In between raw data and information use for management practices. Journal of Cleaner Production, 197(Part 1), 1056-1068. doi.org/10.1016/j.jclepro.2018.06.194

Lu, Y., \& Abeysekera, I. (2014). Stakeholder' power, corporate characteristics, and social and environmental disclosure: Evidence from China. Journal of Cleaner Production, 64(February), 426-436. doi.org/10.1016/j.jclepro.2013.10.005

Makori, D. M., \& Jagongo, A. (2013). Environmental accounting and firm profitability: An empirical analysis ofselected firms listed in Bombay Stock Exchange, India. International Journal of Humanities and Social Science, 3(18), $248-256$.

Mata, C., Fialho, A., \& Eugénio, T. (2018). A decade of environmental accounting reporting: what we know? Journal of Cleaner Production, 198(10), 1198-1209. doi. org/10.1016/j.jclepro.2018.07.087
Mathuva, D. M., \& Kiweu, J. M. (2016). Cooperative social and environmental disclosure and financial performance of savings and credit cooperatives in Kenya. Advances in Accounting, 35(December), 197-206. doi.org/10.1016/j. adiac.2016.09.002

Mchavi, N. D., \& Ngwakwe, C. C. (2017). Relationship between environmental pressure \& environmental disclosure in the sustainability reports of banks. Environmental Economics, 8(3), 111-118. doi.org/10.21511/ee.08(3-1).2017.03

Md Nor, N., Bahari, N. A. S., Adnan, N. A., Kamal, S. N. Q. A. S., \& Ali, I. M. (2016). The Effects of environmental disclosure on financial performance in Malaysia. Procedia Economics and Finance, 35(2016), 117-126. doi:10.1016/S22125671(16)00016-2

Meng, X. H., Zeng, S. X., Shi, J. J., Qi, G. Y., \& Zhang, Z. B. (2014). The relationship between corporate environmental performance and environmental disclosure: An empirical study in China. Journal of Environmental Management, 145(December), 357-367. doi.org/10.1016/j. jenvman.2014.07.009.

Michelon, G., Pilonato, S., \& Ricceri, F. (2015). CSR reporting practices and the quality of disclosure: An empirical analysis. Critical Perspectives on Accounting, 33(Dec.), 59-78. doi.org/10.1016/j.cpa.2014.10.003

Mnasri, K. (2015). Ownership structure, board structure and performance in the Tunisian banking industry. Asian Academy of Management Journal of Accounting and Finance, 11(2), 57-82.

Mousa, G. A., \& Hassan, N. T. (2015). Legitimacy theory and environmental practices: Short notes. International Journal of Business and Statistical Analysis, 2(1), 41-53. doi.org/10.12785/ IJBSA/020104

Musa, S. J., Peter, T., \& Bukar, M. (2015). Environmental accounting disclosure practice of Nigerian quoted firms: A case study of some selected quoted consumer goods companies. Research Journal of Finance and Accounting, 6(22), 31-37.

Nguyen, L. S., \& Tran, M. D. (2019). Disclosure levels of environmental accounting information and financial performance: The case of Vietnam. Management Science Letters, 18(9), 557-570. doi:10.5267/j.msl.2019.1.007 
Nwaobia, A. N. (2015). Theories in accounting research. In J. N. Nwachukwu, A. O. Ogundiwin, \& A. N. Nwaobia (Eds.). Anthology of Theories and their Applications in Social \& Management Sciences (pp. 27-58). Lagos: Jamiro Press Link.

Qian, W., Hörisch, J., \& Schaltegger, S. (2018). Environmental management accounting and its effects on carbon management and disclosure quality. Journal of Cleaner Production, 174(10), 1608-1619. doi.org/10.1016/j. jclepro.2017.11.092

Raath, S. P., Kanyimba, A. T., De Sousa, L. O., \& Richter, B. W. (2018). The influence of an environmental management system on the environmental worldviews of selected Namibian and South African in-service teachers. International Journal of Environment and Sustainable Development, 17(4), 347-365. doi:10.1504/IJESD.2018.096861.
Sheila, N. H., Rashid, H. M., Mohammed, A. A., \& Meera, A. K. (2012). Impact of corporate governance on social and environmental information disclosure of Malaysian listed banks: Panel data analysis. Asian Journal of Finance and Accounting, 4(1), 1-24. doi:10.5296/ajfa.v4i1.810

Uwuigbe, U. (2012). Web-based corporate environmental reporting in Nigeria: A study of listed companies. Informatica Economica, 16(3), 27-36.

Uwuigbe, U., \& Egbide, B. (2013). Corporate environmental disclosures in Nigeria: A study of listed financial and nonfinancial firms. Journal of Management Sustainability, 2(1), 160-169.

Zyznarska-Dworczak, B. (2018). Legitimacy theory in management accounting research. Problemy Zarzadzania - Management Issues, 16(1(72), 195-203. doi:10.7172/16449584.72.12.

\section{Received on $15^{\text {th }}$ December 2019, after revision, accepted for publication on $13^{\text {th }}$ April 2020 \\ Published online on $24^{\text {th }}$ April 2020}

Edirin Jeroh, $\mathrm{PhD}$, is a senior lecturer at the Department of Accounting \& Finance of the Delta State University (DELSU), Abraka, Nigeria. 


\title{
PROCENA UNUTRAŠNJIH DETERMINANTI PRAKSI EKOLOŠKOG IZVEŠTAVANJA KOJE PRIMENJUJU PREDUZEĆA U REGIJI PODSAHARSKE AFRIKE
}

\author{
Edirin Jeroh \\ Delta State University, Department of Accounting, Abraka, Delta State, Nigeria
}

U radu je sprovedena komparativna analiza internih determinanti praksi ekološkog izveštavanja, koje primenjuju preduzeća u Podsaharskoj Africi. Da bi se navedena analiza sprovela, prikupljeni su podaci o karakteristikama mera odbora i revizorskih komisija na uzorku od 60 privrednih društava iz čitavog regiona (po 20 iz Kenije, Nigerije i Južne Afrike). Tehnika regresije običnih najmanjih kvadrata korišćena je za analizu podataka, a rezultati do kojih se došlo pokazuju da, dok se karakteristike mera odbora i revizije prepoznaju kao značajne determinante ekološkog izveštavanja preduzeća u Keniji i Nigeriji, isto se ne može reći za preduzeća u Južnoj Africi. Imajući u vidu navedeni razlog, u studiji se formulišu preporuke da bi, kada se radi o pozajmljivanju iz Južne Afrike, prakse ekološkog upravljanja trebalo institucionalizovati na nivou čitavog regiona. Donosioci standarda bi dodatno trebalo da učine praktične napore na razvijanju novih standarda izveštavanja, koji će predstavljati smernice i podsticati preduzeća da u svojim ekološkim izveštajima u celosti prikažu sporna pitanja od ekološkog značaja.

Ključne reči: Podsaharska Afrika, finansijsko izveštavanje, ekološko upravljanje, korporativno upravljanje, odbor direktora

JEL Classification: G34, M40, M41 